\title{
Compliance with the Balance of Private and Public Interests During Expulsion of Foreign Citizens
}

\author{
Elena E. Andreychenko* \\ Siberian Federal University \\ 79 Svobodny, Krasnoyarsk, 660041, Russia
}

Received 26.05.2017, received in revised form 09.06.2017, accepted 15.06.2017

The article determines criteria for restricting the rights and limits of the state intervention in the privacy of foreigners when expelled from the host country. The author believes that the migration policy is carried out by the state independently, and the restriction of entry and exit is aimed at protecting its own citizens and maintaining law and order. Expulsion must be provided for by the law, it is necessary in a democratic society and must pursue a legitimate aim, and the law must meet certain qualities of the law. The decision on expulsion must be made by the competent authorities in compliance with the balance of public and private interests. The author recommends that the national courts take into account the decisions of the European Court of Human Rights considering a subsidiary nature of its decisions.

Keywords: expulsion, migrants, balance of private and public interests, prescribe by law, legitimate aim, necessary in a democratic society, limitation of rights and freedoms, public interest, private interest, proportionality.

DOI: 10.17516/1997-1370-0101.

Research area: law.

\section{Introduction into the problem}

Migration flows are of a global nature. Residents of the countries of Africa and the Middle East rush to Europe and America in search of a better life. In Russia, some regions are attractive for migrants, including the Krasnoyarsk Territory. According to the Office of the Federal State Statistics Service for the Krasnoyarsk Territory, the Republic of Khakassia and the Republic of Tyva, a total of 14,471 foreigners have arrived in the Krasnoyarsk Territory (Statistical Indicators, 2016).
Unlike the Russian Federation, Germany's migration policy has always been open and willing to accept foreigners in the country. According to the Federal Office for Migrants and Refugees in the first months of 2017, 33,475 applications for asylum and legal status of residence were registered. For the period JanuaryFebruary people who arrived from Syria occupy the first place (20.6\%). The second place is taken by Afghanistan (9.6 \%) and Iraq (8.9\%) (Fig. 1).

German Chancellor Angela Merkel, since her accession in 2005, has proclaimed a policy

(C) Siberian Federal University. All rights reserved

* Corresponding author E-mail address: borodino45@yandex.ru 


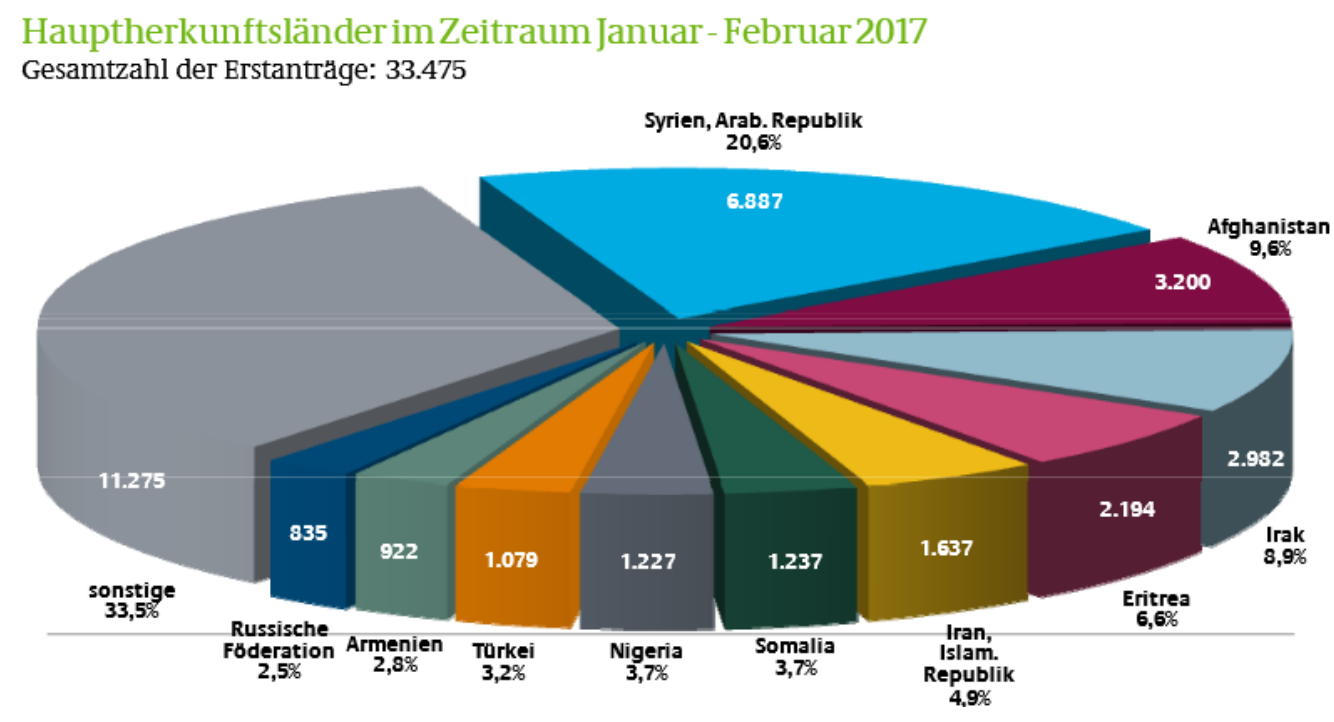

Fig. 1. Statistische Zahlen, 2017

of multiculturalism by opening borders and inviting migrants to the territory of Germany. However, in connection with the arrival of a large number of refugees from Syria and the East in Europe, migration issues are an acute topic. Headlines of the media indicate that the focus on "multiculturalism" has failed, and the current situation with the inrush of Syrian refugees is already a big problem for the authentic population of the country.

The German authorities are actively discussing the possibility or the impossibility of expelling refugees of the Syrian Civil War.

According to the constitutional provisions of both states, foreign citizens have the right to be in the territory of the foreign state. Let us note that the majority of foreigners who have arrived in the territory of another state take care of the legal grounds for their stay, they integrate into the society by building business, personal and social ties. However, not all foreigners arriving in the territory of another state act in lawful ways. Many cross the border in violation of migration rules and the established regime of entry.

The state is independent in the implementation of its migration policy and has the right to restrict the entry and stay of foreign citizens in the territory of the country, including, in order to fully protect its own citizens and guarantee a stable legal order (Kravchenko, 2004). The state has the right to deport illegal migrants and persons who stay within the country without permissive grounds.

According to statistical data (Statistical indicators, 2016) for 2016, 1,200 foreign citizens and stateless persons were deported from the Krasnoyarsk Territory administratively, and in regards of 118 people the judicial decisions of deportation were executed.

Foreigners do not always take into account the changing rules of stay and can get into situations that entail their expulsion. However, in some cases the expulsion may violate their rights.

\section{Statement of the problem}

Despite the fact that the migration policy is aimed at protecting the public interest, we believe that when deporting foreigners, migration services should take into account the private interests of those subject to expulsion.

When examining migration measures and policies, it is necessary to understand how 
to balance the private and public interests in cases where the presence of a particular foreign individual adversely affects the well-being of the population. On the one hand, the public order and the peace of citizens are placed on the scales, and on the other hand, foreigner's family, personal and intimate relations are often intervened.

It is noted that "in some cases, the decision of expulsion from a country is an encroachment on a personal and family life of deportees or members of their families" (Tereshkova, 2007).

In this regard, a question arises whether the state is free to establish restrictions and what the limits of the state interference in the privacy of foreigners staying in its territory are.

O.S. Orekhov identifies criteria that affect the margin of appreciation of states, thereby determining the basis on which the limits of discretion are set. Firstly, the criterion of the protected public interest. The more important the protected public interest and, correspondingly, the greater the social danger that threatens it, the greater discretion will be available to the states in preventing this threat. Secondly, the criterion of the presence or absence of consensus on a certain issue concerning internal affairs between the member states of the Council of Europe: the discretion "will already be where there is a strong consensus on a particular issue among the participating States, if more broadly, where there is no such consensus" (Orekhov, 2015).

Thus, the discretion of the state to implement the migration policy is limited.

\section{Methodology}

In order to study the balance of private and public interests and the criteria for its compliance, the article uses a technical method, a comparative law method and such general scientific methods as analysis, synthesis, historical, logical and systemic methods.
The empirical basis of the study was the practice of the European Court of Human Rights (A.L. (X.W.) v. Russia, 2015; Alim v. Russia, 2011; Beldjoudi v. France, 1992 and others).

Conclusions are based on the analysis of judicial practice, the decisions of the national courts and the materials of the migration service of the Krasnoyarsk Territory have been analyzed.

\section{Discussion}

Issues of migration policy have been studied by both Russian and foreign scientists for a long time. I.S. Vlasov (Artemov; Vlasov; Golovanova, 2007), N.A. Golovanova (Artemov, Vlasov, Golovanova, 2007), N.A. Kulichenko (Kulichenko, 2012) have devoted their works to the problems of migration processes.

Theoretical bases of migration processes and policies of Germany have been considered by foreign scientists such as K. Schönwälder (2004), B. Hess (2009), and T. Jürgens (1987).

In connection with the large number of violations of the rights of migrants during expulsion, scientists have made recommendations for national courts and migration authorities.

Scientists formulate recommendations for finding a balance of interests in cases when the legitimate expulsion of a foreigner violates both his rights and the rights of his family and offer criteria for determining this balance (Tereshkova, 2007, 2017; Thym, 2008). Determination of criteria and grounds for limiting the rights of foreigners and balance of interests is a subject of the activities of the international judicial bodies. The European Court of Human Rights has repeatedly used the principle of proportionality and the criteria for maintaining the balance of interests in its decisions. The issue of correlation of private and public interests was the subject of research (Sharnina, 2005).

The concept of the proportionality of restriction of rights has been discussed in the 
practice of the European Court of Human Rights, as well as in the doctrine of international law since the seventies of the past century (Mikhailov, 2016).

The doctrine states that the proportionality test originated in the German public law (Grimm, 2007) presumes a series of consistent questions that answer the question of the legitimacy of the purpose of restricting rights.

Any restriction of rights must meet the following conditions:

- Firstly, such a restriction must be provided for by law.

- Secondly, a restriction must pursue a legitimate aim.

- Thirdly, it should be necessary in a democratic society.

- And, finally, the principle of proportionality must be observed (Tereshkova, 2007, 2017).

When expelling foreigners, first of all, the court must be guided by the requirements of the law. In other words, the court determines whether deportation is prescribed by the law. The law must meet the requirements of the "quality of law". The ECtHR unfolds the notion of "quality of law" noting several factors. The court points out that the law should be expressed in clear language so that individuals can have an idea of what consequences and in what cases may be followed by its violation (Lupsa v. Romania, 2006). In addition, unlimited discretionary powers should not be given to state bodies, it is necessary to establish "the limits of discretion of the competent authorities and the manner of its implementation with sufficient clarity taking into account the legitimate aim of the measure in question, in order to provide a person with adequate protection against arbitrary interference with his rights" (Lupsa v. Romania, 2006).

However, in the Liu and Liu case (Liu and Liu v. Russian Federation, 2007); the requirements of the "quality of law" have not been met.
Thus, spouses living in the Khabarovsk Territory addressed the ECHR with a complaint against the Russian Federation (Liu and Liu v. the Russian Federation, 2007). The male applicant stayed in Russia on the basis of a visa, he is married with the female applicant and has a child with her. In 2002, almost a year before the expiration of his visa, the applicant applied to the FMS authorities for the issuance of a residence permit, which he was denied due to the lack of necessary application forms. On a specified date, Liu applied again, but he was refused to issue a residence permit for unknown reasons. Later, the applicant was brought to administrative responsibility for being on the territory of the Russian Federation without permits. After numerous trials, in 2006 the city court ruled on his deportation.

The European Court of Human Rights found Russia to be in breach of Paragraph 2 of Article 8 of the Convention for the Protection of Human Rights and Fundamental Freedoms with regard to interference with the applicant's family life, since the law did not meet the quality requirements.

The authorities may refuse a person a permit for residence because this person is a threat to the state security or illegally resides in the country. In this case there is no exhaustive list of actions that entail a threat to national security and public peace; here the authorities have wide discretion. At the same time it is important to take into account that there should be statutory guarantees against abuse of discretion by the authorities. In the case of Liu and Liu v. Russian, there was a possibility of a judicial appeal against the refusal, but the court could not conduct an effective assessment of the situation, since all the materials of the representatives of the internal affairs bodies amounted to confidential information.

In cases where the decisions of state authorities are based on the law, it is necessary that expulsion be considered by an authorized 
entity as necessary in a democratic society. In this case, it is important that the "proportionality between the measures applied by the authorities and the legitimate aims pursued" is observed (Liu and Liu v. Russia, 2007).

A citizen of Tajikistan was expelled from Krasnoyarsk for having violated the regime of stay in Russia by residing without permits. The Krasnoyarsk regional court upheld the decision of the court of the first instance in force, since "a citizen... has been resided in the territory of the Russian Federation without legal grounds for a long time (more than 2 years), has not taken necessary measures to obtain documents confirming the right to stay (reside) in the Russian Federation and has not applied to the bodies of the Federal Migration Service on this issue. He does not have a permanent job and does not own any immovable property. Marriage to a Russian citizen... has been terminated, children live with their mother" (Case No. 7P-169/2014, 2015).

The judicial authorities restricted the right of a citizen of Tajikistan to stay on the territory of the Russian Federation.

Expulsion from the country was based on the law, since the Russian Federation established the procedure for stay of foreigners within the state, for violation or non-fulfilment of which there is an appropriate administrative punishment.

The analysis of the case shows that the Tajik citizen's interest to stay in the Russian Federation was so weak that he himself did not even made efforts to stay. He did not keep in touch with his children, he was separated from his wife for a long time, he had no permanent job, and therefore had no stable social ties.

The national court has lawfully taken a decision on his deportation, since the balance of private and public interests was observed.

In the case "Salem v. Denmark" (Salem v. Denmark, 2016), the European Court of Human Rights found no violation from the side of the
European Convention and recognized deportation as legal, because the threat to public order and the well-being of the state turned out to be more serious than separation from children.

M.K. Salem arrived in Denmark from Lebanon, where he married a Danish woman of Lebanese origin, had eight children with her and received a residence permit. In 2010, Salem was convicted of 18 crimes related to drug trafficking. Later, the applicant was deported from the country, despite having eight children. An important role was played by the fact that Salem did not manage to blend into the Danish society and maintained contact with Lebanon. Thus, a person convicted of numerous crimes, representing a public danger to Denmark was expelled by a decision taken in accordance with the law, requirements in a "democratic society" and with the purpose of achieving a legitimate aim.

But the national courts not always take a judicious approach to the determination of the balance of public and private interests. The decision on deportation can be based on law, pursue a legitimate aim, but not be necessary in a democratic society, since expulsion will result in unfavourable consequences for a foreigner and his family.

Similar circumstances were investigated in the European Court of Human Rights in 1988 (Berrehab v. the Netherlands, 1988). A Moroccan citizen, A. Berrehab, who lives in the Netherlands, was denied an extension of his residence permit, despite the fact that he had an underage daughter who was born in wedlock to a Dutch citizen. The Government of the Netherlands referred to the fact that because of the growth of the population of the country it was necessary to regulate the labour market, and separation from ex-wife and daughter was not sufficient grounds for establishing the fact of family life. This example is significantly different in that Mr. Berrehab 
defended his right to reside in the Netherlands confirming his private interest in the fact that "before the expulsion he saw his daughter four times a week... each meeting lasted for several hours. The frequency and regularity of visits with his daughter prove that Mr. Berrehab attached great importance to them".

On the one hand, the mechanism of expulsion was respected: the state issued a law that Berrehab violated, society is interested in legal migrants, the state seeks to regulate the labour market, and on the other hand, the applicant's desire to raise his daughter in care and attention and not to lose close ties with his ex-family. This shows that the national court has not made attempts to establish a balance of public and private interests.

The balance of public and private interests, in our opinion, implies a fair, reasonable and proportionate weighing of the issues of national security and personal life.

A fair balance between interests in cases of expulsion of foreign citizens is achieved due to the fact that the state in each particular case must investigate the negative consequences of a person's stay within the country for the whole society, and the risks that fall on a foreigner during his deportation. An important role here is played by social ties established with the host state of a person, his adaptation, communicative opportunities in the state of his citizenship.

Rationality is manifested in an adequate assessment of reality, and proportionality is expressed in the fact that the actions of the state and expulsion of a foreigner must "be based on the primary need of society" and must be proportionate to the goal pursued by the state.

From the point of view of balance, on the one hand, it is necessary to take into account the interests of society in security, stability and peace, and on the other hand, there will always be an opposition of a particular individual who, perhaps, cannot be left to his fate.

\section{Conclusion}

Migration policy is carried out by the state independently. Only the state, based on its sovereign rights, can establish the procedure for entry, exit and stay, measures of responsibility for violation of the regime for the stay of foreigners within the country.

The right to determine the migration policy is not absolute, and the borders of the state's discretion in cases of illegal stay and expulsion may be limited. Criteria for limiting rights were formulated by the European Court of Human Rights in many cases.

First of all, expulsion must be provided for by the law, the law must meet the legal standards established by international judicial bodies (to be accessible and foreseeable, there are guarantees against abuse).

Intervention measures should be "necessary in a democratic society".

Any decision on expulsion must pursue a legitimate aim.

There must always be a balance of interests. Each executor of law, by his inner conviction and principles, is obliged to be guided by the weighing and proportionality of the threat to the public interests and the negative consequences that a foreign citizen will incur.

In this regard, the national courts are recommended to take into account the decisions of the ECtHR, which interpreted the provisions of the Convention for the Protection of Human Rights and Fundamental Freedoms to be applied in the dispute under consideration. In cases where the European Court finds a violation of human rights and freedoms in the application of the law or its separate provisions in the Russian Federation, the national courts, knowing the subsidiary character of the judgments of the European Court, should suspend the proceedings and appeal to the Constitutional Court of the Russian Federation with a request to verify compliance with the Constitution of the Russian Federation. 


\section{References}

Aktuelle Zahlen zu Asyl. Bundesamt fuer Migration und Fluechtlinge. Tabellen Diagrame Erlaeuterungen. Ausgabe: Februar 2017. Available at: http://www.bamf.de/SharedDocs/Anlagen/DE/ Downloads/Infothek/Statistik/Asyl/aktuelle-zahlen-zu-asyl-februar-2017.pdf?_blob=publicationFile

Artemov, V.Iu., Vlasov, I.S., Golovanova N.A. (2007). Migratsiia i prestupnost': sravnitel'nopravovoi analiz [Migration and crime: a comparative legal analysis]. Moscow, Institute of Legislation and Comparative Law under the Government. KONTRACT, 142-145.

Asylgesetz. 1. (1992). BGBl. I S. 1126. Available at: https://www.google.com/ search?q=http\%3A\%2F\%2Fwww.gesetze-im+internet.de\%2Fasylvfg_1992\%2FBJNR111260992.htm 1\%23BJNR111260992BJNG000104311\&ie=utf-8\&oe=utf-8

Dikhtiar, A.I., Rogozhin, N.A. (2002). Obespechenie balansa chastnykh i publichnykh interesov v sudebnykh resheniiakh Konstitutsionnogo Suda RF [Ensuring the balance of private and public interests in judgments of the Constitutional Court of the Russian Federation]. In Zakon i pravo [Law and Justice], 12. Available at: http://www.echr.ru/news/msg.asp?id_msg=97

Grimm D. (2007). Proportionality in Canadian and Germany Constitutional Jurisprudence. In University of Toronto Law Journal, 57. 383 p.

Hess, Barbara. (2009). Bleiben hochqualifizierte Zuwanderer in Deutschland? In Migration und Ethische Minderheiten, 2, 16

Jürgens, Thomas. (1987). Diplomatischer Schutz und Staatenlose. Berlin, 53 p.

Kondrashev, A.A., Tereshkova, V.V. (2017). Balans chastnykh i publichnykh interesov v kontekste mezhdunarodnykh standartov i konstitutsionnogo zakonodatel'stva Rossiiskoi Federatsii [Balance of private and public interests in the context of international standards and constitutional legislation of the Russian Federation]. The draft article in the journal "State and Law" presented by the scientific adviser V.V. Tereshkova.

Krasnoyarsk Regional Court. Case No. 7P-169/2014. The decision of the Krasnoyarsk regional court dated May 15, 2014. Electronic fund of legal and normative technical documentation. Available at: http://docs.cntd.ru/document/495405589.

Kravchenko, O.Iu. (2004). Publichnye i chastnye interesy v prave: politico-pravovye interesy [Public and private interests in law: political and legal research]. Abstract of the dissertation. Available at: http://dspace.kpfu.ru/xmlui/bitstream/handle/net/30767/130105_4.pdf.

Kulichenko, N.A. (2012). Konstitutsionnoe pravo na svobodu peredvizheniia v Rossii i Germanii [Constitutional right to freedom of movement in Russia and Germany]. Stavropol: Publishing House of SSU, $160 \mathrm{p}$.

Merkel erklärt Multikulti für gescheitert. In SPIEGEL ONLINE. Available at: http://www.spiegel. de/politik/deutschland/integration-merkel-erklaert-multikulti-fuer-gescheitert-a-723532.html.

Mikhailov, A.A. (2016). Printsip proportsional'nosti: sushchnost', praktika primeneniia Evropeiskim sudom RF i znachenie dlia sovershenstvovaniia sistemy dokazyvaniia v sovremennom ugolovnom protsesse Rossii [The principle of proportionality: the essence, practice of application by the European Court of Human Rights, the Constitutional Court of the Russian Federation and the importance for improving the system of proof in the modern criminal process in Russia]. In Ugolovnaia iustitsiia [Criminal Justice], 1 (7).

Orekhov, O.S. (2015). O predelakh svobody usmotreniia gosudarstv v praktike Evropeiskogo suda po pravam cheloveka [On the limits of the discretion of states in the practice of the European Court 
of Human Rights]. In Vestnik Volzhskogo universiteta im. V.N. Tapishcheva [Bulletin of the Volzhsky University named after V.N. Tatishchev], 2 (82).

RBC. IGIL vziala na sebia otvetstvennost' za vzryv v Bavarii [ISIS claimed responsibility for the explosion in Bavaria]. In RBC-news, stocks, exchange rates, dollar, euro. Available at: http://www. rbc.ru/politics/25/07/2016/579625269a79473ca315f70d.

RIA News. Velikoe pereselenie migrantov: chislo zhertv pobega za mechtoi rastet [The great resettlement of migrants: the number of victims chasing after the dream is growing]. In RIA NEWS Russia today. Available at: https://ria.ru/world/20150828/1213235315.html.

Schonwalder, K., Vogel, D. and Sciortino, G. (2004). Migration und Illegalitaet in Deutschland. In Berlin: AKI-Forschungsbilanz I, Arbeitsstelle Interkulturelle Konflikte und Gesellschaftliche Integration, Wissenschaftszentrum Berlin für Sozialforschung.

Sharnina, L.A. (2005). Chastnye i publichnye interesy v konstitutsionnom prave [Private and public interests in constitutional law]. In Konstitutsionnoe i munitsipal'noe pravo [Constitutional and municipal law], 4, 12.

Statistical indicators of activity for January-December 2016. Main Directorate of the Ministry of Internal Affairs of Russia for the Krasnoyarsk Territory. Available at: https: //24.md.rf/ms/ Statisticheskie_svedenija

The concept of the state migration policy of the Russian Federation for the period until 2025 (approved by the President of the Russian Federation). Reference legal system "ConsultantPlus".

The European Court of Human Rights. Application No. 44095/14. The case of "A.L. (X.W.) v. Russia". Judgment dated 29.10.2015. Reference legal system "ConsultantPlus".

The European Court of Human Rights. Application No. 39417/07. The case of "Alim v. Russian Federation". Judgment dated 27.09.2011. Reference legal system "ConsultantPlus".

The European Court of Human Rights. The case of "Beldjoudi v. France". Judgment dated 26.03.1992, Information-Legal Portal "Garant".

The European Court of Human Rights. Application No. 10730/84. Case of "Berrehab v. the Netherlands". Judgment dated 21.06.1988. Available at: http://europeancourt.ru/tag/obshhestvennayabezopasnost-statya-8/.

The European Court of Human Rights. Application No. 10337/04. The case of "Lupsa v. Romania". Judgment dated 18.05.2006. Available at: http://docs.pravo.ru/document/view/15794583/12862186/.

The European Court of Human Rights. Application No. 42086/05. The case of "Liu and Liu v. the Russian Federation". Judgment dated 06.12.2007. Reference legal system "ConsultantPlus".

The European Court of Human Rights. Application No. 12313/86. The case of "Moustaquim v. Belgium". Judgment dated 18.02.1991. Information-Legal Portal "Garant".

The European Court of Human Rights. Application No. 77036/11. The case of "Salem v. Denmark". Judgment dated 01.12.2016. Reference legal system "ConsultantPlus".

The European Court of Human Rights. Application No. 22414/93. The case of "Chakhal v. The United Kingdom". Judgment dated 15.11.1996. Available at: http://europeancourt.ru/tag/vysylka/.

The Supreme Court of the Russian Federation. Resolution of the Plenum of the Supreme Court of the Russian Federation dated December 19, 2003 No. 23 "On the legal judgment". Reference legal system "ConsultantPlus".

The Supreme Court of the Russian Federation. Resolution of the Plenum of the Supreme Court of the Russian Federation dated June 27, 2013 No. 21 "On the application by the courts of general 
jurisdiction of the Convention for the Protection of Human Rights and Fundamental Freedoms dated November 4, 1950 and the Minutes thereto". Reference legal system "ConsultantPlus".

Tereshkova, V.V. (2007). Primenenie mezhdunarodnykh norm o zashchite prav cheloveka national'nymi sudebnymi organami [Application of international standards on the protection of human rights by national judicial authorities]. In Sovremennoe sostoianie teorii, zakonodatel'stva i praktiki konstitutsionnogo prava zarubezhnykh stran [The current state of theory, legislation and practice of constitutional law of foreign countries], 215-222.

Thym, D. (2008). Respect for private and family life under article 8 ECHR in immigration cases: a human right to regularize illegal stay? In International and Comparative Law Quarterly, 57(1), 87-112.

Voskobitova, M.R. (2011). Pozitivnye obiazatel'stva gosudarstv kak garantiia obespecheniia prav cheloveka i osnovnykh svobod [Positive obligations of states as a guarantee of ensuring human rights and fundamental freedoms]. In Mezhdunarodnoe pravosudie [International justice], 1.

Why did Merkel change her mind about the refugees? In Expert online. Available at: http://expert. ru/2015/09/16/merkel-peredumala/

Zueva, A.S., Khabibulin, A.G. (2016). Zadachi i funktsii sovremennoi rossiiskoi gosudarstvennosti v sfere migratsionnoi politiki [The tasks and functions of modern Russian statehood in the field of migration policy]. In Migratsionnoe pravo [Migration law], 2, 22-26.

\title{
Соблюдение баланса частных \\ и публичных интересов \\ при высылке иностранных граждан
}

\author{
Е.Э. Андрейченко \\ Сибирский федеральный университет \\ Россия, 660041, Красноярск, пр. Свободный, 79
}

Статья посвящена определению критериев ограничения прав и пределов вмешательства государства в частную жизнь иностранцев при высылке с территории страны пребывания. Автор утверждает, что миграционная политика осуществляется государством самостоятельно, а ограничение въезда и выезда направлено на защиту собственных граждан и поддержание правопорядка. Высылка должна быть предусмотрена законом, необходима в демократическом обществе, должна преследовать правомерную цчель, закон должен отвечать определенньм качествам закона. Решение о выдворении должно приниматься компетентныли органами при соблюдении баланса публичного и частного интересов. Автор рекомендует национальньлм судам учитывать решения Европейского суда по правам человека, принимая во внимание субсидиарный характер его постановлений.

Ключевые слова: высылка, мигранты, баланс частных и публичных интересов, предписывание законом, законная иель, необходимый в демократическом обществе, ограничение прав и свобод, публичные интересы, частные интересы, пропоричональность.

Научная специальность: 12.00.00 - юридические науки. 